\title{
EDITORIAL: "CAVE AND KARST SCIENCE IN ITALY"
}

This issue of Acta Carsologica collects some of the papers presented by Italian karstologists in the session "Above and Under Karst: new horizons in karst geomorphology" held during the "VIIth Forum Italiano di Scienze della Terra" at Rimini on September 11, 2009. This was the first time that karst was represented in this biennial geological congress that counts around 2000 participants.

The karst session gathered 28 presentations, 8 of which have been grouped in a poster session and the 20 remaining in three oral blocks. More than 80 people attended these sessions, enriched by many interesting discussions and, at the end of the session, a round table debate on the future of scientific karst research in Italy.

Our invitation to submit the final papers to a special issue of Acta Carsologica has been appreciated by most participants, and after peer review, 15 papers have been accepted for publication.

Most of these papers concern Italian karst areas, but three are related to other countries: India, Mexico and Croatia. The Indian karst area (Mandhip Khol cave, Chhattisgarh State) has never previously been reported in the scientific literature. The Naica caves, on the contrary, have been one of the hot topics of the last 5 years. The paper presented here tries to put the giant gypsum crystal's growth in a chronological frame, confronting U/Th datings with experimental growth rate measurements. The third paper describes some peculiar coastal karst morphologies in Istria (Croatia).

Of much more general nature is the paper on morphometric analysis of cave systems, one of the new frontiers in karst geomorphology thanks to the use of powerful computers and progressively more sophisticated softwares.
The 11 other papers, as previously said, concern different karst areas located in 7 Italian regions, from South to North: Sicily, Sardinia, Apulia, Campania, Tuscany, Umbria, Veneto and Friuli Venezia Giulia.

Sicily is characterised by large outcrops of Messinian gypsum, and the geomorphology and evolution of one of the most interesting of these karst areas, the Monte Conca cave system, is illustrated, based on recent speleological explorations.

Measuring caves has experienced very important technical improvements in the last decades, with computer programs, laser distance meters and 3D tools. Laser scanning is increasingly adoperated in caves, and these techniques are explained in a paper on a case study in Sardinia, the Santa Barbara mine cave system.

A classical geomorphological paper concerns the Murge karst plateau in Apulia, while sinkhole morphology and origin in Campania region is discussed in another paper.

Caves are often important spots that can help in reconstructing the geomorphological evolution of sometimes large areas: this is illustrated in the study on the Corfino and Soraggio karst areas in Tuscany.

In the last years much has been written on hypogenic caves and speleogenesis. These studies have been carried out in many Italian regions, and the Frasassi cave system is probably among the best known examples. An overview of hypogenic caves in western Umbria is given here.

Two papers deal with the same karst area in Veneto: the Cansiglio plateau. Recent investigations have tried to unravel its hydrogeology with traditional tracing techniques, but also through precise geodetic measurements. 
Following two papers deal with recent and paleo environmental conditions in caves. The first one reports on a combined hydrological and climatological research in Monte Corchia cave system in Tuscany, and the second on a reconstruction of paleoenvironment based on pollen analyses in Tanella cave in Verona.

Finally, the impact of a railway tunnel in the Classical Karst near Trieste (Val Rosandra) is illustrated.

This Issue, although containing many studies carried out in Italy, gathers several fine researches that make use of the most modern investigation techniques, or give good overviews of regional karst. We hope the readership of Acta Carsologica will appreciate these papers.

We would like to thank all the karst people that attended the session at the congress, and especially the editors Franci Gabrovšek and Andrej Kranjc for having accepted to publish these papers, Nataša Ravbar and Elisabeth D. Covington for the editing and proof-reading of all papers and the over 40 reviewers that have helped the authors to improve their papers.

Jo De Waele and Paolo Forti, guest editors 